\title{
Slow Nerve Conduction Velocity in Cretins
}

\author{
A. MOOSA and V. DUBOWITZ \\ From the Department of Child Health, University of Sheffield
}

\begin{abstract}
Moosa, A., and Dubowitz, V. (1971). Archives of Disease in Childhood, 46, 852. Slow nerve conduction velocity in cretins. The ulnar and posterior tibial conduction velocities were measured in 6 untreated and 3 treated cretins. In 4 of the untreated patients, the conduction velocity of both nerves was slower than normal; in 1 patient the ulnar and in the other the posterior tibial nerve conduction velocity was slower than normal. There was a close agreement between bone age and the age corresponding to the slow conduction velocities. The 3 treated cretins all had normal posterior tibial conduction velocities, while the ulnar conduction velocity was normal in one, slower in another, and faster than normal in the third.

The slow nerve conduction velocity in cretins probably reflects a delay in maturation of the peripheral nerves. Nerve conduction velocity measurement may be a useful screening test in suspected congenital hypothyroidism, and may also prove of value in assessing response to therapy.
\end{abstract}

It is well known that neonatal hypothyroidism leads to mental retardation. Necropsy studies have shown that the brains of cretins have defective myelination and poorly developed cell processes (French and Van Wyk, 1964). An increase in slow wave activity and a decrease in amplitude of the EEG have been noted (Nieman, 1961; Harris, Della Rovere, and Prior, 1965), and Schultz et al. (1968) showed that the development of sigma rhythm was retarded. Experimental studies on newborn rats made hypothyroid have also shown a decrease in the size of cortical neurones and in the density of axon networks and branching of dendrites (Eayrs, 1955, 1960).

In contrast to the extensive studies on the central nervous system, there have been very few studies on the effect of thyroid deficiency on the maturation of the peripheral nervous system. In their review on motor nerve conduction velocity, Dunn et al. (1964) mentioned a single cretin infant whose nerve conduction velocity was slower than normal.

Since thyroid deficiency reduces the formation of brain myelin in hypothyroid rats (Walravens and Chase, 1969), one might anticipate a similar effect on peripheral nerve myelination. This would in turn be reflected by a slowing of conduction velocity in the motor nerve and we have accordingly investigated this in a series of human cretins.

Received 18 May 1971.

\section{Material and Method}

The ulnar and posterior tibial nerve conductiono velocities were measured in 9 patients with congenitak. hypothyroidism. 5 of these were infants under the age of 1 year, and 4 were over 1 year. In 6 infants the conduction velocities were measured before any treatment was started. The 3 others had been on treatment for periods ranging from 4 weeks to $8 \frac{1}{2}$ years (Table).

The method was similar to that described by Hodes, Larrabee, and German (1948). The ulnar nerve was stimulated at the elbow and the wrist and the evoked muscle response was recorded from the hypothenar muscles. The posterior tibial nerve was stimulated in the popliteal fossa and behind the medial malleolus and the evoked response recorded from the flexor hallucis brevis. The stimulus consisted of a square wave impulse of $0.1 \mathrm{msec}$ duration and variable amplitude. Maximum response was ensured by increasing the stimulus intensity until no further increase in motor response occurred with increasing stimulus intensity. The response was photographed (Polaroid) and the latencies calculated from the stimulus artefact to the first well defined negative peak of the response. The difference in latencies between the proximal and distal responses was divided into the intercathodal distance to give the conduction velocity in $\mathrm{m} / \mathrm{sec}$.

The patients were examined at room temperature. None of them was hypothermic. The results were compared with those of normal infants and children examined under the same conditions.

In the 5 infants under 1 year, the estimated postconceptional age (gestational age plus chronological 
TABLE

\begin{tabular}{|c|c|c|c|c|c|c|c|c|c|}
\hline \multirow{2}{*}{ Case No. } & \multirow{2}{*}{$\begin{array}{c}\text { Gestational } \\
\text { Age* } \\
\text { (wk) }\end{array}$} & \multirow{2}{*}{$\begin{array}{c}\text { Chronological } \\
\text { Age }\end{array}$} & \multirow{2}{*}{$\begin{array}{c}\text { Post- } \\
\text { conceptional } \\
\text { Aget (wk) }\end{array}$} & \multirow{2}{*}{ Bone Age } & \multicolumn{2}{|c|}{$\begin{array}{l}\text { Conduction Velocity } \\
(\mathrm{m} / \mathrm{sec})\end{array}$} & \multirow{2}{*}{$\begin{array}{c}\text { Post-conceptional } \\
\text { Age Estimated } \\
\text { from } \\
\text { Conduction } \\
\text { Velocity }\end{array}$} & \multirow{2}{*}{$\begin{array}{c}\text { PBI } \S \\
(\mu \mathrm{g} / 100 \mathrm{ml})\end{array}$} & \multirow{2}{*}{ Treatment } \\
\hline & & & & & Ulnar & $\begin{array}{l}\text { Posterior } \\
\text { Tibial }\end{array}$ & & & \\
\hline $\begin{array}{l}1 \\
2 \\
3 \\
4 \\
5 \\
6 \\
7 \\
8\end{array}$ & $\begin{array}{l}42 \\
44 \\
42 \\
39 \\
42 \\
- \\
- \\
- \\
-\end{array}$ & $\begin{array}{l}4 \mathrm{mth} \\
11 \mathrm{mth} \\
3 \mathrm{mth} \\
1 \mathrm{mth} \\
9 \mathrm{mth} \\
5 \mathrm{yr} \\
18 \mathrm{mth} \\
9 \mathrm{yr} \\
9 \mathrm{yr}\end{array}$ & $\begin{array}{l}59 \\
92 \\
55 \\
43 \\
81 \\
- \\
- \\
- \\
-\end{array}$ & $\begin{array}{c}38 \mathrm{wk} \ddagger \\
- \\
35 \mathrm{wk} \ddagger \\
32 \mathrm{wk} \ddagger \\
<4 \mathrm{mth} \\
<4 \mathrm{mth} \\
<4 \mathrm{mth} \\
7 \mathrm{yr} \\
\text { (at } 8 \mathrm{yr} \text { ) } \\
\end{array}$ & $\begin{array}{l}26 \cdot 7 \\
29 \cdot 3 \\
28 \cdot 1 \\
20 \cdot 9 \\
34 \cdot 0 \\
41 \cdot 0 \\
46 \cdot 3 \\
46 \cdot 0 \\
72 \cdot 2\end{array}$ & $\begin{array}{l}24 \cdot 5 \\
28 \cdot 2 \\
16 \cdot 4 \\
20 \cdot 5 \\
21 \cdot 9 \\
40 \cdot 5 \\
39 \cdot 7 \\
42 \cdot 4 \\
47 \cdot 6\end{array}$ & $\begin{array}{l}40 \mathrm{wk} \\
47 \mathrm{wk} \\
38 \mathrm{wk} \\
36 \mathrm{wk} \\
41 \mathrm{wk} \\
- \\
- \\
- \\
-\end{array}$ & $\begin{array}{l}0 \cdot 5 \\
0 \cdot 5 \\
2 \cdot 0 \\
2 \cdot 9 \\
2 \cdot 0 \\
1 \cdot 0 \\
2 \cdot 0 \\
1 \cdot 9 \\
3 \cdot 1\end{array}$ & $\begin{array}{c}\text { No } \\
\text { No } \\
\text { No } \\
\text { No } \\
\text { No } \\
\text { No } \\
\text { Yes } \times 4 \mathrm{wk} \\
\text { Yes } \times 8 \frac{1}{2} \text { yr } \\
\text { Yes } \times 8 \frac{1}{2} \text { yr }\end{array}$ \\
\hline
\end{tabular}

age) based on the combined ulnar and posterior tibial conduction velocity was obtained (Moosa, 1971).

\section{Results}

The relevant data on the patients are given in the Table. The conduction velocities are plotted in the Fig. 4 of the 6 untreated cretins had both ulnar and posterior tibial conduction velocities below the normal range. In the other 2 , one had ulnar nerve conduction velocity below the normal range, and one had posterior tibial nerve conduction velocity below the normal range, with the conduction velocity of the other nerve at the lower limit of normal.

The 3 treated cretins all had normal posterior tibial conduction velocities, while the ulnar conduction velocity was normal in one, slower in another, and faster in the third.

In each of the 5 infants the age calculated from the conduction velocity was considerably less than the true post-conceptional age. In 3 of these infants there was good agreement between the bone age and the age corresponding to their conduction velocity; in 1 infant bone age was not available; and in the other infant bone age of less than 4 months was determined from the wrist only.

\section{Discussion}

The results indicate that the conduction velocity of infants suffering from congenital hypothyroidism is slower than normal. This slowing may be due to the effect of generalized metabolic changes induced by thyroid deficiency on the function of the peripheral nerves. This is generally accepted as the explanation for the slow conduction velocity in some adult patients with myxoedema, while in others it may be due to entrapment (a carpaltunnel syndrome) or segmental demyelination.

The peripheral nerves of infants and young children, however, differ from those of adults in
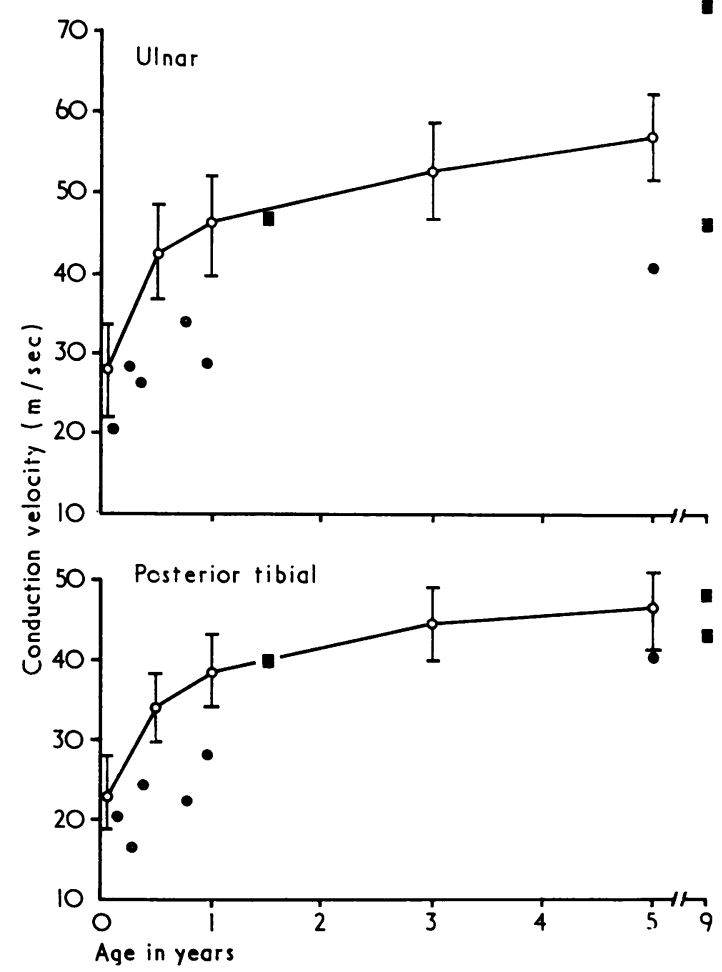

Fig.-Nerve conduction velocities in untreated (closed circle) and treated (closed squares) cretins. The open circles are the mean velocities for normal infants and children and the bars on either side represent $2 S D$ of the mean. 
one important aspect. Whereas the adult nerves are fully mature, those of infants and young children are still undergoing myelination. This occurs rapidly during intrauterine and early postnatal life, and slows later. It is reflected by a corresponding increase in conduction velocity.

The slow conduction velocity of the hypothyroid infants may therefore indicate retarded maturation of the peripheral nerves. In support of this is the close agreement between bone age and the age corresponding to the slow conduction velocity. Moreover, thyroxin deficiency is known to interfere with myelin lipid production; and accelerated maturation of peripheral nerves in a newborn of a thyrotoxic mother has been recorded (Schulte, Albert, and Michaelis, 1969).

Patients with hypothyroidism often have subnormal temperature. It is well known that reduction in temperature results in a corresponding slowing of nerve conduction. Hypothermia is unlikely to be the explanation for the slow conduction velocity in the above patients, since none of them was hypothermic.

The normal posterior tibial conduction velocities of the 3 treated cretins suggest that the maturation of the peripheral nerves returns to normal following institution of therapy. The faster and slower than normal ulnar conduction velocity in 2 of the infants may indicate overtreatment and undertreatment, respectively.

The results of the present study suggest that measurement of the conduction velocity of a peripheral nerve may be a useful screening test for suspected congenital hypothyroidism in infants. Further prospective studies are needed to determine whether, in addition, conduction velocity measurements can be used to assess the efficacy of treatment.

We wish to thank our paediatric colleagues for the opportunity to study patients under their care, and the Muscular Dystrophy Group of Great Britain and the United Sheffield Hospitals Endowment Fund for financial support.

\section{REFERENCES}

Dunn, H. G., Buckler, W. St. J., Morrison, G. G. E., and Emery, A. H. (1964). Conduction velocity of motor nerves in infants and children. Pediatrics, 34, 708.

Eayrs, J. T. (1955). The cerebral cortex of normal and hypothyroid rats. Acta Anatomica, 25, 160.

Eayrs, J. T. (1960). Influence of the thyroid on the central nervous system. British Medical Bulletin, 16, 122.

French, F. S., and Van Wyk, J. J. (1964). Fetal hypothyroidism. fournal of Pediatrics, 64, 589.

Harris, R., Della Rovere, M., and Prior, P. F. (1965). EEG studies in infants and children with hypothyroidism. Archives of Disease in Childhood, 40, 612.

Hodes, R., Larrabee, M. G., and German, W. (1948). The human electromyogram in response to nerve stimulation and conduction velocity of motor axons. Archives of Neurology and Psychiatry, 60, 340.

Moosa, A. (1971). A Study of Motor Nerve Conduction Velocity in Newborn Infants. M.D. Thesis, University of Sheffield.

Nieman, E. A. (1961). The EEG in congenital hypothyroidism: a study of 10 cases. Fournal of Neurology, Neurosurgery and Psychiatry, 24, 50.

Schulte, F. J., Albert, G., and Michaelis, R. (1969). Gestationsalter und Nervenleitgeschwindigkeit bei normalen und abnormen Neugeborenen. Deutsche medizinische Wochenschrift, 94, 599.

Schultz, M. A., Schulte, F. J., Akiyama, Y., and Parmelee, A. H., Jr. (1968). Development of electroencephalographic sleep phenomena in hypothyroid infants. Electroencephalography and Clinical Neurophysiology, 25, 351.

Walravens, P., and Chase, H. P. (1969). Influence of thyroid on formation of myelin lipids. Fournal of Neurochemistry, 16, 1477.

\section{Addendum}

Since submitting this manuscript 5 of the 6 untreated cretins have had their nerve conduction velocities measured after treatment. The results are given in the Table below.

All the conduction velocities are now within theo normal range.

\begin{tabular}{c|c|c|c}
\hline \multirow{2}{*}{ Case No. } & Age & Conduction Velocity (m/sec) \\
\cline { 3 - 4 } & & Ulnar & $\begin{array}{c}\text { Posterior } \\
\text { Tibial }\end{array}$ \\
\hline 1 & $27 \mathrm{mth}$ & 53.3 & 50.0 \\
3 & $16 \mathrm{mth}$ & 52.2 & 45.4 \\
4 & $13 \mathrm{mth}$ & 52.5 & 38.2 \\
5 & $15 \mathrm{mth}$ & 43.0 & 39.8 \\
6 & $6 \mathrm{yr}$ & 56.4 & 42.7 \\
\hline
\end{tabular}

Correspondence to Dr. V. Dubowitz, Department of Child Health, The Children's Hospital, Western Bank, Sheffield S10 2TH. 